\title{
Fundamental Rights, the European Anti-Fraud Office (OLAF) and a European Public Prosecutor's Office (EPPO): Some Selected Issues
}

\section{Fundamental Rights in the OLAF-context: Importance and Sources}

The importance of fundamental rights in the context of OLAF investigations ${ }^{1}$ was acknowledged by the EU legislator already at the time of OLAF's creation. ${ }^{2}$ The $10^{\text {th }}$ recital in the preamble to the OLAF-Regulation states that investigations must be conducted by OLAF "with full respect for human rights and fundamental freedoms, in particular the principle of fairness, for the right of persons involved to express their views on the facts concerning them and for the principle that the conclusions of an investigation may be based solely on elements which have evidential value". The OLAF-Regulation does not, however, contain specific rules on fundamental rights in the context of OLAF investigations. ${ }^{3}$ Such rules, primarily relating to the right to be heard, can be found in the decisions adopted by each EU institution implementing Article 4(1), second subparagraph, and Article 4(6) of the OLAF-Regulation ${ }^{4}$ as well as in the OLAF Instructions to Staff on Investigative Procedures. ${ }^{5}$

Moreover, since OLAF is a part of the European Commission, the general rules on fundamental rights applicable in the EU context also apply to its investigations. These rules currently have three sources. The most relevant source nowadays is the Charter of Fundamental Rights of the EU, ${ }^{6}$ which has become legally binding with the entry into

1 This article is inspired by and further develops the analysis in relation to fundamental rights in J. F. H. Inghelram, Legal and Institutional Aspects of the European Anti-Fraud Office (OLAF) - An Analysis with a Look Forward to a European Public Prosecutor's Office (Europa Law Publishing, 2011). The views expressed in this article are strictly personal. The author is grateful to Prof. Dr. C. W. A. Timmermans, P.-J. Loewenthal and P. Schönberger for their valuable comments on an earlier draft.

2 OLAF was established by Commission Decision of 28 April 1999 establishing the European Anti-Fraud Office (OLAF), O.J. 1999, L 136/20, hereinafter the OLAF-Decision. Its investigative competences are primarily governed by Regulation (EC) No 1073/1999 of the European Parliament and of the Council of 25 May 1999 concerning investigations conducted by the European Anti-Fraud Office (OLAF), O.J. 1999, L 136/1, hereinafter the OLAF-Regulation.

3 This may change if the Commission's proposal for an amendment to the OLAF-Regulation is adopted. For the latest version of this proposal, see COM(2011) 135 final.

4 See, in this respect, the Interinstitutional Agreement of 25 May 1999 between the European Parliament, the Council of the European Union and the Commission of the European Communities concerning internal investigations by the European Anti-fraud Office (OLAF), O.J. 1999, L 136/15. The model decision annexed to this Agreement served as a basis for the adoption by these three institutions of their decisions.

5 http://ec.europa.eu/anti_fraud/documents/instructions-to-staff-111222_en.pdf, hereinafter the OLAF Instructions. These Instructions have replaced the OLAF Manual on Operational Procedures (hereinafter the OLAF Manual) as from 1 Febr. 2012.

6 O.J. 2007, C 303/1. 
force of the Treaty of Lisbon. ${ }^{7}$ However, already prior to the entry into force of that Treaty, it was well-established that the EU institutions (and, therefore, also OLAF) are required to respect fundamental rights. Indeed, according to settled case-law, fundamental rights form an integral part of the general principles of law whose observance the EU courts ensure. ${ }^{8}$ There is no reason to believe that this second source of general rules on fundamental rights would cease to exist after the entry into force of the Lisbon Treaty.

Furthermore, it can be argued that, with the entry into force of that same Treaty, Articles 6 and 8 of the Convention for the Protection of Human Rights and Fundamental Freedoms (ECHR), ${ }^{9}$ which deal with the fundamental rights to a fair trial and to privacy, have become applicable in the EU legal order, despite the fact that the EU has not yet acceded to this Convention. ${ }^{10}$ This seems to follow from Article 52(3) of the Charter, according to which rights in the Charter corresponding to rights guaranteed by the ECHR have the same meaning and scope as those latter rights. In this manner, Articles 6 and 8 ECHR would constitute a third source of law already existing in the EU legal order.

It is not the intention of this article to discuss in detail the fundamental rights which are of primary importance in the context of OLAF investigations, namely the right to privacy, the rights of the defence and the right to an effective remedy. ${ }^{11}$ Rather, the objective is to analyse some selected issues in relation to each of these three fundamental rights which could be of relevance to the OLAF investigative framework and beyond, including to a future EPPO.

\section{The Fundamental Right to Privacy and the Issue of Supervision}

OLAF's investigative competences are quite far-reaching, particularly in relation to internal investigations, which are investigations carried out within the EU institutions, bodies, offices and agencies. ${ }^{12}$ OLAF has the right of immediate and unannounced access to any information held by any of these entities and to their premises, ${ }^{13}$ a right which includes access to the offices and computers of EU officials. These far-reaching powers

7 Art. 6(1) TEU.

8 See, e.g., C-305/05, Ordre des barreaux francophones et germanophones and Others, [2007] ECR I-5305, para 29.

9 These two provisions are the relevant ECHR provisions for the purposes of this article.

10 See on that accession, Art. 6(2) TEU.

11 See, in this respect, e.g., Opinion No 5/2010 of the OLAF Supervisory Committee on "Respect for fundamental rights and procedural guarantees in investigations by the European AntiFraud Office", O.J. 2011, C 188/37; S. Gleß and H. E. Zeitler, "Fair Trial Rights and the European Community's Fight Against Fraud", 7 ELJ (2001), 219-237; V. Stojanovski, "Procedural Rights of Persons under Investigation by OLAF", (2011) Eucrim, 127-132; and J. F. H. Inghelram, cited supra note 1, 88-92, 103-107, 127-168, 230.

12 As opposed to external investigations carried out in the Member States and in third countries; see OLAF-Regulation, Arts. 3 and 4.

13 OLAF-Regulation, Art. 4(2), first indent. 
may bring within OLAF's reach information which belongs to the private sphere, ${ }^{14}$ thus triggering the application of the fundamental right to privacy laid down in Article 7 of the Charter and Article 8 ECHR. ${ }^{15}$

The fact that an OLAF investigative act interferes with the right to privacy of a person does not necessarily mean that it also violates that right, since interference may be justified if certain conditions are met. According to Article 52(1) of the Charter (hereinafter: the horizontal exception clause), "[a]ny limitation on the exercise of the rights and freedoms recognised by [the] Charter must be provided for by law and respect the essence of those rights and freedoms. Subject to the principle of proportionality, limitations may be made only if they are necessary and genuinely meet objectives of general interest recognised by the Union or the need to protect the rights and freedoms of others." This provision is similar to Article 8(2) ECHR, according to which interference by a public authority with the exercise of the right to privacy is possible if it "is in accordance with the law and is necessary in a democratic society in the interests of national security, public safety or the economic well-being of the country, for the prevention of disorder or crime, for the protection of health or morals, or for the protection of the rights and freedoms of others". ${ }^{16}$

For such interference with the right to privacy to be justified, the European Court of Human Rights has underlined the need for adequate protection against arbitrary measures to be provided for by the applicable legislation, which implies that access to an independent authority, preferably a court, must be guaranteed. ${ }^{17}$

At first sight, this requirement echoes the fundamental right to an effective remedy, provided for by Article 47 of the Charter and Article 6 ECHR. It is, however, interesting to note that this procedural requirement of having access to an independent authority is, in the case-law of the European Court of Human Rights, inherent in Article 8 ECHR itself. A similar approach of a procedural requirement inherent in a substantive fundamental right provision can be found in the ECJ's Kadi Case, ${ }^{18}$ where that Court held,

14 OLAF itself referred to examples in this respect in the OLAF Manual, section 3.3.2.1, under (3). See also the (theoretical) examples of the search and seizure of personal effects during OLAF investigations as well as of the clandestine tapping of telephone conversations, cited by the Council and the Commission in Joined Cases F-5/05 and F-7/05, Violetti and Others v. Commission, judgment of 28 April 2009, not yet reported, para 66.

15 On the right to privacy as a general principle of EU law, see, e.g., Joined Cases C-465/00, C-138/01 and C-139/01, Österreichischer Rundfunk and Others, [2003] ECR I-4989, para 68.

16 See ibid., para 71, for a similar restriction to the right to privacy as a general principle of EU law.

17 See, e.g., Société Colas Est and Others v. France, judgment of 16 April 2002, Reports of Judgments and Decisions 2002-III, para 49; Association for European Integration and Human Rights and Ekimdzhiev v. Bulgaria, judgment of 28 June 2007, no. 62540/00, para 87; and Buck v. Germany, judgment of 28 April 2005, Reports of Judgments and Decisions 2005-IV, para 46. In Petri Sallinen and Others v. Finland, judgment of 27 September 2005, no. 50882/99, in which the European Court of Human Rights found that, in relation to a search and seizure, Art. 8 ECHR had been violated, it was "struck by the fact that there was no independent or judicial supervision" (at para 89).

18 Joined Cases C-402 \& 415/05 P, Kadi and Al Barakaat International Foundation v. Council and Commission, [2008] ECR I-6351, para 368. 
with reference to the case-law of the European Court of Human Rights, ${ }^{19}$ that the right to be heard is inherent in Article 1 of Protocol No 1 to the ECHR. In that case, Mr Kadi's fundamental right to respect for property was found to be infringed by the mere fact that the regulation ordering the freezing of his funds had been adopted without furnishing any guarantee enabling him to put his case to the competent authorities.

Currently, access to an independent authority in the OLAF context does not exist, at least not at the non-judicial level. ${ }^{20}$ The OLAF Supervisory Committee, which, as its name suggests, is the primary supervisor of OLAF, does not have any decision-taking power towards the latter and, it has been expressly stated, it cannot interfere with the conduct of investigations in progress. ${ }^{21}$ The Supervisory Committee therefore does not have the powers to act as the "independent authority" to which an individual should have access in order to be protected against arbitrary measures.

In its latest proposal of 17 March 2011 for an amendment to the OLAF-Regulation, ${ }^{22}$ the Commission proposed the introduction of a review procedure to be put into place within OLAF. A member, staff member or a natural person concerned by an investigation could ask the person or persons entrusted with this internal review procedure to give an opinion regarding the observance of procedural guarantees. However, the person or persons charged with this procedure would not have any decision-taking power towards OLAF. Moreover, contrary to the members of the Supervisory Committee, they would not be independent from OLAF, since they would remain under the authority of its Director-General. Access to this review procedure cannot therefore be seen as access to an "independent authority".

Nevertheless, a (non-judicial) mechanism providing for access to an "independent authority", as required by the case-law of the European Court of Human Rights to respect the fundamental right to privacy, is well conceivable. This is demonstrated, for instance, by the proposal of the European Court of Auditors, in its Opinion No 6/2011 of 12 July 2011 on the Commission's proposal, ${ }^{23}$ to create the function of a review officer completely independent from the Director-General of OLAF and having the power to issue "binding opinions" at the request of persons concerned by an OLAF investigation.

The issue of access to an independent authority is not without practical relevance. Indeed, the mere absence of such access when an OLAF investigative act interferes with the fundamental right to privacy may lead to the conclusion that this right has been violated, however justified the objectives of such an interference may otherwise have been. This, in turn, demonstrates that adequate supervision over OLAF is an issue which not only benefits persons under investigation by OLAF, but also OLAF itself.

19 Jokela v. Finland, judgment of 21 May 2002, Reports of Judgments and Decisions 2002-IV, paras. 45 and 55.

20 For the role of the EU courts in this respect, see infra under IV.3.

21 OLAF-Regulation, Art. 11(1), second subparagraph. See also Special Report No 2/2011 'Follow-up of Special Report No 1/2005 concerning the management of the European Anti-Fraud Office?' of the European Court of Auditors, O.J. 2011, C 124/9, where it is concluded that “ [t]here is still no independent control of the legality of investigative acts in progress" (para $39)$.

$22 \operatorname{COM}(2011) 135$ final.

23 O.J. 2011, C 254/1, para 40. 


\section{Fundamental Rights of the Defence}

Several rights of the defence are relevant in the OLAF context. Reference can be made to the right to be heard, the right of access to the file, the right to be informed, the right to assistance of a legal counsel, the presumption of innocence, the right not to incriminate oneself and the right to remain silent, the reasonable-time requirement, and the duty of impartiality. Three selected issues will be discussed below in their broader context, namely, the right to be heard and the possibility of deferral of this right under the Charter; the right of access to the file and the confidentiality exception under the Charter; and the right not to incriminate oneself and the distinction between "administrative" and "criminal".

\section{The Fundamental Right to be Heard and the Possibility of Deferral of this Right under the Charter}

It has long been established case-law that respect for the right to be heard is a general principle of EU law. That principle requires that the addressees of decisions which significantly affect their interests should be placed in a position in which they may effectively make known their views on the evidence on which the contested decision is based. ${ }^{24}$ It has been implemented in the OLAF context in the decisions adopted by each EU institution pursuant to Article 4(1), second subparagraph, and Article 4(6) of the OLAF-Regulation (for internal investigations) ${ }^{25}$ as well as in the OLAF Instructions. ${ }^{26}$

These OLAF instruments provide for a possibility to defer the right to be heard in certain circumstances which are related to the necessity of maintaining absolute secrecy for the purpose of the investigations and/or the existence of national judicial proceedings. In this respect, the question arises to what extent the right to be heard can be deferred until after the adoption of the act to which this right relates (for instance, until after the adoption of the OLAF investigation report and its transmission to national judicial authorities). ${ }^{27}$

In the case-law, it has been accepted that implementation of the right to be heard can be postponed until after the measure to which the right relates has been taken, for instance, to safeguard the effectiveness of a freezing of funds measure ${ }^{28}$ or in special circumstances where it is impossible in practice, or incompatible with the interest of the service, to hold a hearing before adopting a decision suspending an EU official. ${ }^{29}$

This approach may need to be nuanced now that the Charter of Fundamental Rights of the EU has become legally binding. Indeed, it follows from Article 41(2)(a) of the Charter $^{30}$ that any hearing must take place before the measure to which the right to be

24 See, e.g., Case C-28/05, Dokter and Others, [2006] ECR I-5431, para 74.

25 See, e.g., Art. 4 of the model decision cited supra note 4.

26 See Art. 18.

27 See on that report, OLAF-Regulation, Art. 9.

28 See the Kadi Case, cited supra note 18, paras. 338 and 339.

29 Case T-211/98, F v. Commission, [2000] ECR SC-I-A-107 and SC-II-471, para 34.

30 "[The right to good administration] includes [...] the right of every person to be heard, before any individual measure which would affect him or her adversely is taken". 
heard relates is taken. Exceptions to this rule are undoubtedly available under the horizontal exception clause of the Charter, so long as they comply with the conditions provided for by this clause. One of these conditions is that the exception "must be provided for by law". 31

If this condition is interpreted in the light of the ECHR, this would mean that the "law" providing for the restriction of a fundamental right must be foreseeable. In other words, the law must be formulated with sufficient precision to enable the citizen - if need be, with appropriate advice - to foresee, to a degree that is reasonable in the circumstances, the consequences which a given action may entail. ${ }^{32}$

In the OLAF context, this condition may well be fulfilled if a restriction to the right to be heard is provided for by the above-mentioned decisions, adopted by the EU institutions in the context of internal investigations, which explicitly implement the OLAFRegulation. On the contrary, it is less likely that this would also be true for the possibility of deferring the right to be heard provided for by the OLAF Instructions, ${ }^{33}$ which currently contain the only rules in this respect applicable to external investigations. These Instructions are in fact no more than a systematic compilation of internal instructions for OLAF staff. It is, therefore, doubtful that the restriction to the fundamental right to be heard in the OLAF Instructions is "provided for by law", as required by the horizontal exception clause in the Charter. In practice, this would mean that, at least for external investigations, there is no valid ground for deferring the right to be heard until after the adoption of the measure to which that right relates, for instance until after the adoption of the investigation report.

This leads to the paradox that the provision on procedural guarantees which the Commission proposed to add to the OLAF-Regulation ${ }^{34}$ may well be of more importance to OLAF itself than to the persons under investigation by OLAF. Indeed, the guarantees themselves essentially exist already on the basis of the general rules on fundamental rights, ${ }^{35}$ contrary to the restrictions to these guarantees, which do not exist unless they are "provided for by law". Therefore, providing for these restrictions in a lawful manner may well be the real added-value of the proposed provision on procedural guarantees.

31 See, on the relevance of this condition, Joined Cases C-92/09 and C-93/09, Volker und Markus Schecke and Eifert, judgment of 9 Nov. 2010, not yet reported, para 66.

32 See Olsson v. Sweden (No. 1), judgment of the European Court of Human Rights of 24 March 1988, Series A no. 130, para 61, under (a).

33 Art. 18(3).

$34 \operatorname{COM}(2011) 135$ final, essentially Art. 7 a.

35 See, e.g., on the right to assistance of a legal counsel, Case 85/87, Dow Benelux v. Commission, [1989] ECR 3137, paras. 25-27. 


\section{The Fundamental Right of Access to the File and the Confidentiality Exception under the Charter}

A right of access to the file is not provided for by the OLAF legal instruments and was even explicitly excluded in the OLAF Manual. ${ }^{36}$ The EU General Court ${ }^{37}$ has also ruled that a right of access to the file cannot be claimed from OLAF, since the effectiveness and the confidentiality of OLAF's mission as well as its independence could be jeopardized if access to the investigation file were granted before the decision-making stage following the investigation. It did not consider this outcome to be contrary to the Charter of Fundamental Rights of the EU because of the exception which that Charter provides to that right in order to respect the legitimate interests of confidentiality. ${ }^{38}$

As a starting point, if abstraction is made of that exception, it seems difficult to deny that there is a right of access to the file in the OLAF context. This follows from a mere reading of Article 41(2)(b) of the Charter ${ }^{39}$ as well as from the case-law on the EU general principle of the rights of the defence. According to this case-law, the right of access to the file is the "corollary" of that principle and requires that the opportunity must be given to examine all the documents in the investigation file which may be relevant for the defence. ${ }^{40}$ If this principle applies in the OLAF context, its "corollary" also does.

In consequence, the question whether a right of access to the file actually exists essentially depends on the scope of the confidentiality exception in Article 41(2)(b) of the Charter. In this respect, it has been argued that the legitimate interests of confidentiality mentioned therein are those of third parties and not those of an EU institution or body itself. ${ }^{41}$ This is, for instance, also true for the obligation of professional secrecy provided for by Article 339 TFEU. $^{42}$ If this reading is correct, OLAF's own interest in keeping an investigation confidential could not justify a refusal of access to the file under Article 41(2)(b) of the Charter. Furthermore, a selective ban on access to the file, insofar as this access actually affects the interests of third parties, could be justified under that provision, but not necessarily an overall ban.

Admittedly, if the confidentiality exception in Article 41(2)(b) of the Charter indeed has the scope as argued above, it is most likely still possible to provide for a restriction to the right to access of the file, based on a need for confidentiality to protect the effec-

36 See section 5.1.3.2.

37 The name "EU General Court" will be used even if the judgments were rendered before the entry into force of the Treaty of Lisbon, when this court was known as the "Court of First Instance of the European Communities".

38 Case T-48/05, Franchet and Byk v. Commission, [2008] ECR II-1585, paras. 255-257.

39 "[The right to good administration] includes [...] the right of every person to have access to his or her file, while respecting the legitimate interests of confidentiality and of professional and business secrecy".

40 Joined Cases C-204/00 P, C-205/00 P, C-211/00 P, C-213/00 P, C-217/00 P and C-219/00 P, Aalborg Portland and Others v. Commission, [2004] ECR I-123, para 68.

41 See S. Braum, "Justizförmigkeit und europäische Betrugsermittlung - Bemerkungen zum Fall Eurostat (EuG T-48/05, Urteil vom 8. 7. 2008)", (2009) JZ, 298-304, 303.

42 In fact, it was with reference to the latter provision, as implemented by Art. 8(2) of the OLAFRegulation, that OLAF justified the absence of a right of access to the file in the OLAF Manual (section 5.1.3.2). 
tiveness of the OLAF investigation, by applying the horizontal exception clause of the Charter. In practice, however, there currently is no such confidentiality exception to the right of access to the file "provided for by law" in the OLAF context.

This implies that refusal of access to the file is entirely dependent on the scope, which is subject to interpretation, of the confidentiality exception in Article 41(2)(b) of the Charter. The question therefore arises whether an application of the horizontal exception clause in the Charter, through an explicit exception to the right of access to the file provided for by the OLAF-Regulation, might not be preferable from the perspective of legal certainty. This would constitute an acknowledgment that the fundamental right of access to the file applies in the OLAF context, at least as a starting point. However, the question is whether this fact can still be denied.

\section{The Fundamental Right Not to Incriminate Oneself and the Distinction between "Administrative" and "Criminal"}

The OLAF-Decision and the OLAF-Regulation stress the administrative character of OLAF investigations. ${ }^{43}$ This qualification is of a relative nature, since it is necessarily determined by a given context. For instance, while Article 6 ECHR applies to procedures implying a "criminal charge" within the meaning of that provision, ${ }^{44}$ it is settled caselaw of the European Court of Human Rights that an administrative procedure which leads to disciplinary measures or to the imposition of a penalty may also fall within its scope. ${ }^{45}$ Therefore, the fact that OLAF investigations are qualified in the OLAF-Regulation as being of an "administrative" nature does not necessarily prevent rules of a "criminal" nature from being applicable to those investigations. Moreover, a distinction has developed in the case-law of the European Court of Human Rights between the application of the "criminal-head guarantees" 46 to the "hard core of criminal law", on the one hand, and to situations falling outside that category but within the scope of Article 6 ECHR, on the other. In the case of the latter, the criminal-head guarantees will not necessarily apply with their full stringency. ${ }^{47}$ However, since OLAF investigations are often a preamble to national criminal prosecutions, ${ }^{48}$ the ECHR guarantees applicable

43 See OLAF-Decision, Art. 2(1), as well as OLAF-Regulation, Art. 2.

44 The first sentence of Art. 6(1) ECHR reads as follows: "In the determination of his civil rights and obligations or of any criminal charge against him, everyone is entitled to a fair and public hearing within a reasonable time by an independent and impartial tribunal established by law." Italics mine.

45 See, e.g., Engel and Others v. the Netherlands, judgment of 8 June 1976, Series A no. 22, paras. 80-82, and Öztürk v. Germany, judgment of 21 Febr. 1984, Series A no. 73, para 49, and for an application of this case-law in the EU context, Case C-45/08, Spector Photo Group and Van Raemdonck, [2009] ECR I-12073, para 42.

46 This term, used by the European Court of Human Rights, refers to the guarantees flowing from Art. 6 ECHR in criminal law matters, as opposed to civil law matters.

47 Jussila v. Finland, judgment of 23 Nov. 2006, Reports of Judgments and Decisions 2006XIV, para 43. For an application of this case-law in the EU context, see, e.g., Case T-138/07, Schindler Holding and Others v. Commission, judgment of 13 July 2011, not yet reported, para 52, as well as W. P. J. Wils, "The Increased Level of EU Antitrust Fines, Judicial Review and the ECHR", 33 World Comp. (2010), 5-29, 15.

48 See also S. Braum, cited supra note 41, 302. 
to the "hard core of criminal law" may well also apply to "administrative" OLAF investigations.

An illustrative example in this respect is the application of the right not to incriminate oneself. This right and the related right to remain silent are closely linked to the presumption of innocence, provided for by Article 48(1) of the Charter. According to the case-law of the European Court of Human Rights, both rights form part of the fair trial requirement under Article 6(1) ECHR. ${ }^{49}$ The OLAF Instructions explicitly refer to these rights by stating twice that the investigators must inform the person concerned of his right not to make any declarations which might be self-incriminating. ${ }^{50}$

There is a potential conflict between both rights and the obligation imposed on EU staff officials, servants and members of EU institutions by the decision adopted by each EU institution or body, ${ }^{51}$ as well as (insofar as officials or servants are concerned) by the Staff Regulations, ${ }^{52}$ to cooperate fully with OLAF and to supply it with information. These obligations are phrased in a general way, without any exception provided for, and a failure to comply with them could result in disciplinary liability.

A similar risk of conflict between the duty to give information and the right not to incriminate oneself exists in the area of competition law, where undertakings under investigation may also be under the obligation to provide the Commission with information. The case-law has struck a balance between this duty and this right by ruling that the Commission is entitled, if necessary by adopting a decision, to compel an undertaking to provide all necessary information concerning such facts as may be known to it, but it may not compel an undertaking to provide it with answers which might involve an admission on its part of the existence of an infringement which it is incumbent upon the Commission to prove..$^{53}$

The question arises whether the right of an EU official or agent under investigation by OLAF not to incriminate himself and his right to remain silent do not completely override any duty on that official or agent to cooperate with OLAF and/or to provide information to the latter, as required by the above cited instruments. A support for this view can be found in the case-law of the European Court of Human Rights, according to which the right not to incriminate oneself presupposes that the prosecution in a criminal case must seek to prove their case against the accused without resort to evidence obtained through methods of coercion or oppression in defiance of the will of the accused.$^{54}$ In particular, the use of compulsory powers to obtain information raises an issue with regard to the right to remain silent and the privilege against self-incrimination when there is a sufficiently concrete link with criminal proceedings. ${ }^{55}$

Therefore, whereas a balance still seems possible between the duty to give information and the right not to incriminate oneself in the field of EU competition law, this balance may entirely tip over in favour of that right in the case of OLAF investigations, due to the close connection between these investigations and the exercise of criminal law com-

49 See Funke v. France, judgment of 25 Febr. 1993, Series A no. 256-A, para 44.

50 Art. 16(2) and (5).

51 See Arts. 1 and 2 of the model decision, referred to supra note 4.

52 See Art. 22 a of the EU Staff Regulations.

53 See, e.g., Case 374/87, Orkem v. Commission, [1989] ECR 3283, paras. 34-35.

54 See Gäfgen v. Germany, judgment of 30 June 2008, no. 22978/05, para 94 and case-law cited.

55 See, to that effect, Weh v. Austria, judgment of 8 April 2004, no. 38544/97, para 56. 
petences by national authorities. The practical consequence of such an interpretation would be that the duty to cooperate fully with OLAF and to supply it with information simply does not apply to officials, servants or members of EU institutions or bodies who are (likely to be) under investigation by OLAF, at the very least if the OLAF investigations may lead to national criminal proceedings against them.

\section{The Fundamental Right to an Effective Remedy}

According to Article 47 of the Charter, "[e]veryone whose rights and freedoms guaranteed by the law of the Union are violated has the right to an effective remedy before a tribunal in compliance with the conditions laid down in this Article [...]". In the case of OLAF, which is a part of the European Commission and thus an EU entity, two remedies primarily come into play, namely an action for annulment filed before the EU courts $^{56}$ and an action for damages filed before those same courts, ${ }^{57}$ both possibly combined with a request for interim relief. ${ }^{58}$

Until now, judicial control over OLAF's investigative activities has been exercised by the EU courts through action for damages $\operatorname{cases}^{59}$ and not through action for annulment cases. This is because actions for annulment against OLAF investigative acts have thus far been considered inadmissible. ${ }^{60}$

However, in action for damages cases judicial protection is obtained long after the contested investigative act, and the act as such is not affected by the EU court's ruling (only compensation for the prejudice created by that act is obtained). Through an action for annulment combined with a request for interim relief, an OLAF investigative act could theoretically first be suspended and then declared void, so as to deprive that act immediately of any effect. Therefore, if fundamental rights need to be protected, the action for annulment is, at first sight, a more "effective" remedy than the action for damages. This seems to justify a closer look at the possibility of introducing such actions as well as the stakes involved in terms of protection of fundamental rights.

56 Art. 263, fourth paragraph, TFEU or, for EU officials, Art. 270 TFEU and Art. 91 of the EU Staff Regulations.

57 Arts. 268 TFEU and 340, second paragraph, TFEU or, for EU officials, Art. 270 TFEU and Art. 91 of the EU Staff Regulations.

58 Arts. 278 and 279 TFEU. See also further J. Inghelram, "Judicial Review of Investigative Acts of the European Anti-Fraud Office (OLAF): A Search for a Balance", 49 CML Rev. (2012), 601-628.

59 See Case T-309/03, Camós Grau v. Commission, [2006] ECR II-1173; Case T-259/03, Nikolaou v. Commission, [2007] ECR II-99*, and Franchet and Byk v. Commission, cited supra note 38.

60 See, e.g., Case T-193/04, Tillack v. Commission, [2006] ECR II-3995, para 82, and Case T-261/09 P, Commission v. Violetti and Others, judgment of 20 May 2010, not yet reported, para 73. 


\section{The Fundamental Right to an Effective Remedy and the Admissibility of Actions for Annulment}

The reason for a finding of inadmissibility in action for annulment cases relating to OLAF investigative acts is the fact that these acts are deemed not to bring about a distinct change in the applicant's legal position. In essence, it follows from the provisions of the OLAF-Regulation - in particular the $13^{\text {th }}$ recital in the preamble and Article 9 - that the findings of OLAF set out in a final report do not automatically lead to the initiation of judicial or disciplinary proceedings, since the competent authorities are free to decide what action to undertake pursuant to a final report and, accordingly, are the only ones that have the power to adopt decisions capable of affecting the legal position of persons in relation to which a report recommends proceedings be instigated. ${ }^{61}$

In this respect, it is indeed settled case-law that only measures the legal effects of which are binding on, and capable of affecting the interests of, the applicant by bringing about a distinct change in his legal position are acts or decisions which may be the subject of an action for annulment. ${ }^{62}$ Moreover, it is difficult to contest that OLAF cannot instruct national judicial authorities to start proceedings, which, had this been otherwise, would have been a rather revolutionary development in the relations between EU institutions and national judicial authorities.

The question remains, however, whether it is not possible to adopt a different approach when an interference with fundamental rights is involved. In this respect, reference can be made to Rendo and Others v. Commission, ${ }^{63}$ in which an act of the European Commission was considered to bring about a distinct change in the legal position of the applicants and thus an act against which an action for annulment was admissible, merely because it deprived those applicants of the effective exercise of their procedural rights. The question arises whether this is not a fortiori true of an act of an EU institution which deprives a person of the effective exercise of his fundamental rights.

In any case, depriving a person of the exercise, or of the benefit, of a fundamental right amounts, in fact, to taking away, entirely or partly, that right from its beneficiary. For instance, if the OLAF investigation report is sent to national authorities without previously hearing the person under investigation, that person may well have the possibility to make observations in relation to that report during subsequent national administrative or judicial proceedings in which the OLAF findings are used. However, that same person's right to be heard as defined by Article 41(2) of the Charter of Fundamental Rights of the EU, which is a right to be honoured by the "institutions, bodies offices and agencies of the Union", ${ }^{64}$ is, in practice, taken away in relation to that report by the mere transmission of the report in such circumstances. Taking away the right of a person is normally an act which produces legal effects for that person.

61 See, e.g., Tillack v. Commission, cited supra previous note, para 69.

62 See, e.g., Case C-362/08 P, Internationaler Hilfsfonds v. Commission, [2010] ECR I-669, para 51, and Case C-131/03 P, Reynolds Tobacco and Others v. Commission, [2006] ECR I-7795, para 54.

63 Case T-16/91, Rendo and Others v. Commission, [1992] ECR II-2417, paras. 54-55.

64 This follows from Art. 41(1) of the Charter. 
It is also worthwhile mentioning the Council's and the Commission's answer to the Civil Service Tribunal's question in Violetti and Others v. Commission ${ }^{65}$ as to what kind of OLAF investigative acts could be qualified as acts bringing about a distinct change in a person's legal position. The examples referred to by these institutions all relate to acts which interfere with the fundamental rights of a person, either the fundamental right to privacy (search of personal effects, clandestine tapping of the telephone) and possibly the fundamental right to property (seizure of personal effects), as well as the fundamental right to liberty and security (questioning with use of unlawful methods).

Moreover, in Société Canal Plus and Others v. France, ${ }^{66}$ the European Court of Human Rights found that Article 6 ECHR was violated in a situation where the applicants could only contest search and seizure orders pronounced against them by the liberties and detention judge in a competition case if an appeal was lodged against the decision on the merits taken by the competition authority. According to the Court, this made the possibility of obtaining judicial review of these orders uncertain, since both the adoption of a decision on the merits and the introduction of an appeal against that decision were first required. Moreover, several years passed between the search and seizure orders and the decision on the merits. The Court stressed that Article 6 ECHR requires appropriate redress, which necessarily implies the certainty, in practice, that effective judicial review can be obtained and, moreover, within a reasonable period of time. ${ }^{67}$

It follows from this ruling that a situation in which - due to the inadmissibility of an action for annulment against an OLAF investigative act - the legality of that act can only be contested before the judge reviewing the decision subsequently taken on the basis of the OLAF investigation may well, in certain circumstances, be problematic under Article 47 of the Charter if, as Article 52(3) of the Charter requires, this provision is given the same meaning and scope as Article 6 ECHR.

Therefore, qualifying an OLAF investigative act depriving a person of the effective exercise, or of the benefit, of a fundamental right as an act bringing about a distinct change in the legal position of that person, which would make the introduction of an action for annulment, combined with a request for interim relief, against that act possible, may not only be a theoretical solution, but also a legal necessity to respect the fundamental right to an effective remedy.

\section{The Fundamental Right to an Effective Remedy and the Extent of Member State Control over the Exercise by OLAF of its Powers of Investigation}

Where necessary, OLAF investigative acts are enforced in the Member States through coercive measures taken by national authorities. Member State authorities are indeed required to give OLAF inspectors such assistance as they require to allow them to di-

65 Cited supra note 14, para 66.

66 Judgment of 21 Dec. 2010, no. 29408/08.

67 Para 40. 
scharge their duties in carrying out an on-the-spot check or inspection. ${ }^{68}$ The question arises to what extent national courts can review the coercive measures by which an OLAF investigative act is enforced, given the fact that review of the validity of that act is an exclusive matter for the EU courts. ${ }^{69}$

A similar question was at issue in Roquette Frères ${ }^{70}$ in the competition law context, where there exists a similar duty of assistance on Member State authorities. The ECJ ruled that the competent national court, called upon to authorise the search and seizures to be carried out in fulfilment of the duty of assistance, may not substitute its own assessment of the need for the investigations ordered for that of the Commission, the lawfulness of whose assessments of fact and law is subject only to review by the EU judicature. In particular, the review carried out by the competent national court, which must concern itself only with the coercive measures applied for, may not go beyond an examination to establish that the coercive measures in question are not arbitrary and that they are proportionate to the subject matter of the investigation. ${ }^{71}$

In turn, the Commission is required to provide that court with explanations showing, in a properly substantiated manner, that it is in possession of information and evidence providing reasonable grounds for suspecting an infringement of the competition rules by the undertaking concerned. However, the competent national court may not demand that it be provided with the information and evidence in the Commission's file on which the latter's suspicions are based. ${ }^{72}$

This delicate balance between national and EU competences may well constitute an example for the way in which the duty imposed on national authorities to assist OLAF in enforcing the latter's powers of investigation should be interpreted. In practice, this would mean, on the one hand, that the review carried out by the national authorities could not go beyond an examination of whether the coercive measures requested by OLAF are not arbitrary and proportionate to the subject matter of the investigation. On the other hand, OLAF would have to give the authorities all the information they need to carry out the review they are required to undertake, without being obliged to provide the latter with the evidence in its files on which the suspicions are based.

However, in Roquette Frères, the ECJ stressed that the (limited) scope of the competent national court's review is determined by the context surrounding the coercive measures to which it relates. ${ }^{73}$ To this context belong a range of fundamental guarantees, one of which is the possibility for an undertaking against which the Commission has ordered an investigation to bring an action for annulment against that decision before

68 Council Regulation (Euratom, EC) No 2185/96 of 11 November 1996 concerning on-the-spot checks and inspections carried out by the Commission in order to protect the European Communities' financial interests against fraud and other irregularities, O.J. 1996, L 292/2, Art. 9 , and OLAF-Regulation, Art. 6(6).

69 Tillack v. Commission, cited supra note 60, para 80, with reference to Case 314/85, FotoFrost, [1987] ECR 4199, para 20.

70 C-94/00, Roquette Frères, [2002] ECR I-9011.

71 Ibid., paras. 39 and 40.

72 Ibid., paras. 61 and 62.

73 Ibid., para 41. 
the EU courts. ${ }^{74}$ In other words, the existence of an effective remedy at the EU level justifies that a more limited scope of review exists at the national level.

Conversely, this may lead to the conclusion that, in the absence of an effective remedy at the EU level, the need for review by national authorities necessarily increases, not because it is their competence to exercise such a review, but merely because of the objective need for such a review, precisely in order to allow persons under investigation to benefit from this fundamental guarantee. This seems to be an additional reason for taking the issue of an effective remedy at the EU level against possible violations of fundamental rights by OLAF investigative acts, and, therefore, of a possible action for annulment against such acts, seriously.

\section{Fundamental Rights, OLAF and the EU Courts}

At this point, it becomes clear how important adequate access to the EU courts is in the context of OLAF investigations and, in particular, the possibility of introducing an action for annulment (combined, if necessary, with a request for interim relief) against an OLAF investigative act, should a violation of a fundamental right by that act occur. The effective availability of this kind of action would indeed lift all doubts as to the existence of an effective remedy as required by Article 47 of the Charter of Fundamental Rights and, in consequence, avoid the possible need of an extended control by Member State authorities over OLAF's powers of investigation in the context of external investigations, motivated by the absence of an appropriate review of these powers at the EU level. Furthermore, the effective availability of an action for annulment could also function as the access to an "independent authority", as required by the case-law of the European Court of Human Rights to respect the fundamental right to privacy, and thus avoid the risk of interferences with that right being considered unjustified merely because no such access otherwise exists. ${ }^{75}$

\section{Relevance for an EPPO}

The Treaty of Lisbon has opened the possibility for the Council to establish an EPPO. Although there are clear differences between an EPPO and OLAF, there are also similarities between the two. Part of the competences of an EPPO will be of an investigative nature and, above all, such an Office will exercise its competences in a specific legal and institutional environment, in which OLAF has been the sole body with - in part similar competences operational for over ten years now. Therefore, whereas Eurojust, from which an EPPO will be established, ${ }^{76}$ might constitute an example for the future practical functioning of an EPPO, OLAF will most likely have been the laboratory for understanding and interpreting, from an EU legal point of view, the competences of an EPPO.

74 Ibid., para 49.

75 See supra under II.

76 Art. 86(1) TFEU. 
In consequence, the above considerations on fundamental rights in relation to OLAF investigative acts should normally also be relevant in relation to investigative and possibly other acts of an EPPO. In this respect, it seems worthwhile to focus on two particular issues.

First, if an EPPO is established, the question will undoubtedly arise as to whether this EPPO will operate under EU-defined common rules of criminal procedure or under national rules of criminal procedure which vary from one Member State to another. ${ }^{77}$ If the latter option is taken, an EPPO will, in fact, be put in a situation analogous to that in which OLAF currently finds itself, with procedural rules of the Member States where investigations are carried out to be observed, ${ }^{78}$ as well as, in addition to those rules, EU rules on the rights of the defence. Indeed, since an EPPO will be an EU entity, the EU general rules on the rights of the defence will apply in any case.

In turn, this may lead to the paradoxical situation where an EPPO is faced with more stringent EU rules on the rights of the defence if the EU legislator does not adopt common rules on criminal procedure than if it does. Indeed, in accordance with the horizontal exception clause, restrictions to those rights, however justified they may be for an EPPO to be able to exercise its mission, are valid only if they are "provided for by law". Therefore, as for OLAF, ${ }^{79}$ an important reason for adopting EU common rules on procedural guarantees may well be their role as a legal basis for the introduction of legitimate restrictions to those guarantees.

Secondly, the OLAF situation in relation to judicial review gives indications on how such review can/should work in relation to acts of an EPPO. On the one hand, the EPPO will exercise the functions of prosecutor in the competent courts of the Member States,${ }^{80}$ which suggests that national courts will have a role to play in reviewing acts of an EPPO. On the other hand, as already mentioned in the OLAF context, national courts have no jurisdiction to determine that acts of EU institutions, bodies, offices or agencies are invalid. Since this rule is embedded in primary EU law, it is questionable whether a regulation ${ }^{81}$ could transfer the competence of analysing the validity of investigative (and other) acts of an EPPO to national courts.

This shows that the answer to the question whether judicial review of acts of the EPPO will be exercised by national courts or by EU courts, cannot be given in terms of "either the one or the other", but will undoubtedly be "both the one and the other". The delicate balance resulting from this situation, where the Roquette Frères solution might serve as a source of inspiration, would constitute an open invitation for cooperation between those courts, in line with what the preliminary ruling procedure already provides. ${ }^{82}$

77 See on this issue, e.g., D. Flore, "La perspective d'un procureur européen", (2008) ERA Forum, 229-243, 242, and J. L. Lopes da Mota, "Eurojust - The Heart of the Future European Public Prosecutor's Office", (2008) Eucrim, 62-66, 63.

78 OLAF-Regulation, Art. 9(2).

79 See supra under III.1.

80 Art. 86(2) TFEU.

81 Adopted under Art. 86(3) TFEU.

82 Art. 267 TFEU. On this procedure as an instrument of cooperation between national and EU courts, see, e.g., Case C-281/02, Owusu, [2005] ECR I-1383, para 49 and case-law cited. 